\begin{tabular}{|c|c|c|}
\hline 3 & $\begin{array}{l}\text { International Journal of Current Research in } \\
\text { Biosciences and Plant Biology }\end{array}$ & \\
\hline $\begin{array}{l}\text { EXCELLENT } \\
\text { PUBLISHERS }\end{array}$ & Journal homepage: www.ijcrbp.com & \\
\hline
\end{tabular}

Original Research Article

doi: https://doi.org/10.20546/ijcrbp.2018.512.008

\title{
Eleutheranthera Poit. ex Bosc. (Asteraceae): A New Genus Record for Tamil Nadu, India
}

\author{
R. Kottaimuthu' ${ }^{1} 3^{*}$, C. Rajasekar2, 3, C. P. Muthupandi ${ }^{1}$ and K. Rajendran ${ }^{1}$ \\ 1Department of Botany, Thiagarajar College, Madurai-625009, Tamil Nadu, India \\ 2Department of Botany, Bharathiar University, Coimbatore, Tamil Nadu, India \\ 3 Presently at: Department of Botany, Alagappa University, Karaikudi-630003, Tamil Nadu, India
}

*Corresponding author.

\begin{tabular}{|c|c|}
\hline Article Info & ABSTRACT \\
\hline $\begin{array}{l}\text { Date of Acceptance: } \\
29 \text { November } 2018 \\
\text { Date of Publication: } \\
\text { 06 December } 2018\end{array}$ & \multirow[t]{3}{*}{$\begin{array}{l}\text { Eleutheranthera ruderalis (Sw.) Sch.-Bip. forms a new generic record for Tamil Nadu } \\
\text { based on collections from Kanyakumari and Sivagangai Districts. Earlier this species } \\
\text { was known to occur in Andaman and Nicobar Islands, Kerala, Karnataka, } \\
\text { Lakshadweep and West Bengal. Detailed description, photo plate and other relevant } \\
\text { notes of the species are provided. }\end{array}$} \\
\hline Keywords & \\
\hline $\begin{array}{l}\text { Additional flora } \\
\text { Asteraceae } \\
\text { Eleutheranthera } \\
\text { Tamil Nadu }\end{array}$ & \\
\hline
\end{tabular}

\section{Introduction}

The sunflower family or the Asteraceae (nom. alt. Compositae) is the largest family of Angiosperms (Funk et al., 2009) with about 1600-1700 genera and more than 24,000 species (Funk et al., 2009). The members of this family are known to occur in all the regions of the earth except Antarctica (Anderberg et al., 2007). Karthikeyan et al. (2009) enumerated 1149 taxa under 193 genera of this family from within the political boundary of India. Recent study by Mitra and Mukherjee (2017) revealed that Asteraceae with its 1314 taxa under 204 genera, distributed into 20 tribes is the most diversified Angiospermic plant family of the Indian flora.

During the course of floristic exploration of Kanyakumari and Sivagangai Districts, the authors have collected some interesting specimens of the family Asteraceae. Critical analysis and perusal of literature (Chowdhury and Mukherjee, 1995; Yang and Hsieh, 2006) confirmed it as Eleutheranthera ruderalis (Sw.) Sch. Bip. This species was first 
recorded from West Bengal (Bennet, 1965; Jana and Mukherjee, 2014), later from Andaman and Nicobar Islands (Vasudeva Rao, 1982), Lakshadweep (Jayaram and Pradeep, 1990), Kerala (Sasidharan and Nambiar, 1981; Nayar et al., 2006, 2014) and Karnataka (Bhat, 1997). Scrutiny of literature revealed that there is no record of the species occurring in the state of Tamil Nadu (Hajra et al., 1995; Henry et al., 1987; Kottaimuthu, 2014; Krishnamurthy et al., 2014; Livingstone and Henry, 1994; Manickam et al., 2003; Matthew, 1995, 1998, 1999; Pallithanam, 2001; Rao et al., 1988; Sankar et al., 2012) and the present communication therefore forms a new distributional record for Tamil Nadu. Based on recent collections and critical study, a detailed description, photo plate and other details are provided here to ease its further collection and easy identification.

\section{Taxonomic Treatment}

Eleutheranthera ruderalis (Sw.) Sch.-Bip. in Bot. Seil. 24: 165. 1866. Bennett in Curr. Sci. 34: 411. 1965; H.J. Chowdhery in Hajra \& al., Fl. India 12: 383. 1995; Sasidh. \& Sivar., Fl. Pl. Thrissur For.: 250. 1996; S. Choudhury \& S. K. Mukherjee in J. Econ. Taxon. Bot. 29(2): 366. 2005; Sunil \& Sivad. Fl. Alappuzha Dist.: 383. 2009. Melampodium ruderalis Sw., Fl. Ind. Occ. 3: 1372. 1806. (Fig.1).

Herbs, annual, erect, up to $50 \mathrm{~cm}$ high, branched; stems sparsely pubescent, ribbed, slender. Leaves opposite, ovate to ovate-lanceolate, shallowly crenate to serrate, slightly attenuate at the base, obtuse to acute at apex, 3-6 $61.5-3 \mathrm{~cm}$, scabrous on both the surfaces, triplinerved from base; petioles $1-1.5 \mathrm{~cm}$ long. Capitulla homogamous, solitary or 2-4 in each axil, 4-6 $\mathrm{mm}$ across; peduncles up to $2 \mathrm{~cm}$ long, drooping. Involucre campanulate, involucral bracts few, 5-8, biseriate, unequal, oblong or oblong-ovate, 5-7 x 1-2.5 mm, obtuse, densely hispid. Florets 6-9, bisexual, each floret subtended by a receptacular bract. Corolla yellow, gamopetalous, tubular, 2-2.5 mm long, 5toothed, minutely pubescent on teeth. Stamens 5, syngenesious, alternipetalous; anthers black, 0.5 $\mathrm{mm}$ long, sagittate at base; filaments linear, $1 \mathrm{~mm}$ long. Ovary inferior, linear-oblong, 1-2 mm long, thinly scabrid; style branches linear, slender, up to $2.5 \mathrm{~mm}$ long, minutely papillose at apex. Achenes 2-4 mm long, shallowly compressed, obovoid, black, warty, minutely white puberulous near the apex.

Flowering and fruiting: February-March.

Distribution: INDIA (Andaman \& Nicobar Island, Karnataka, Kerala, Sikkim, Tamil Nadu [present report] \& West Bengal), AFRICA, C. \& S. AMERICA, FIJI, INDONESIA, NEW GUINEA, SINGAPORE, SRI LANKA and TAIWAN.

Biotic association: In Kanyakumari, it is often found along with Cleome rutidosperma, Lindernia antipoda, Lobelia alsinoides and Struchium sparganophorum. In Sivagangai, it is commonly associated with Croton hirtus, Cajanus scrabaeoides, Dipteracanthus prostratus, Galactia tenuiflora, Phyllanthus maderaspatensis and Senna uniflora.

Specimens examined: Tamil Nadu: Kanyakumari Distr., Vadivalai, along the bunds of banana fields, 21.02.2018, 95m, R. Kottaimuthu 32120 \& 32122 (Thiagarajar College Herbarium); Sivagangai Distr., Alagappa University, near Science block entrance, 07.08.2018, $R$. Kottaimuthu and $C$. Rajasekar 1 \& 2 (Alagappa University Herbarium).

Note: Eleutheranthera is a monotypic genus of Asteraceae native to Tropical America and naturalized in Java, Ceylon, Papua New Guinea and Fiji (Dassanayake, 1987). It belongs to the tribe Heliantheae of Asteraceae (Panero, 2007) and it can be easily identified in the field by its homogamous capitula nodding, anthers free and tuberculate cypselae. Eleutheranthera ruderalis closely resembles Synedrella nodiflora. However, it can be distinguished from $S$. nodiflora by its homogamous head with drooping peduncles (vs heterogamous head, sessile), calyx absent (vs calyx represented by pappus scales) and achenes obovoid (vs achenes oblanceolate). 

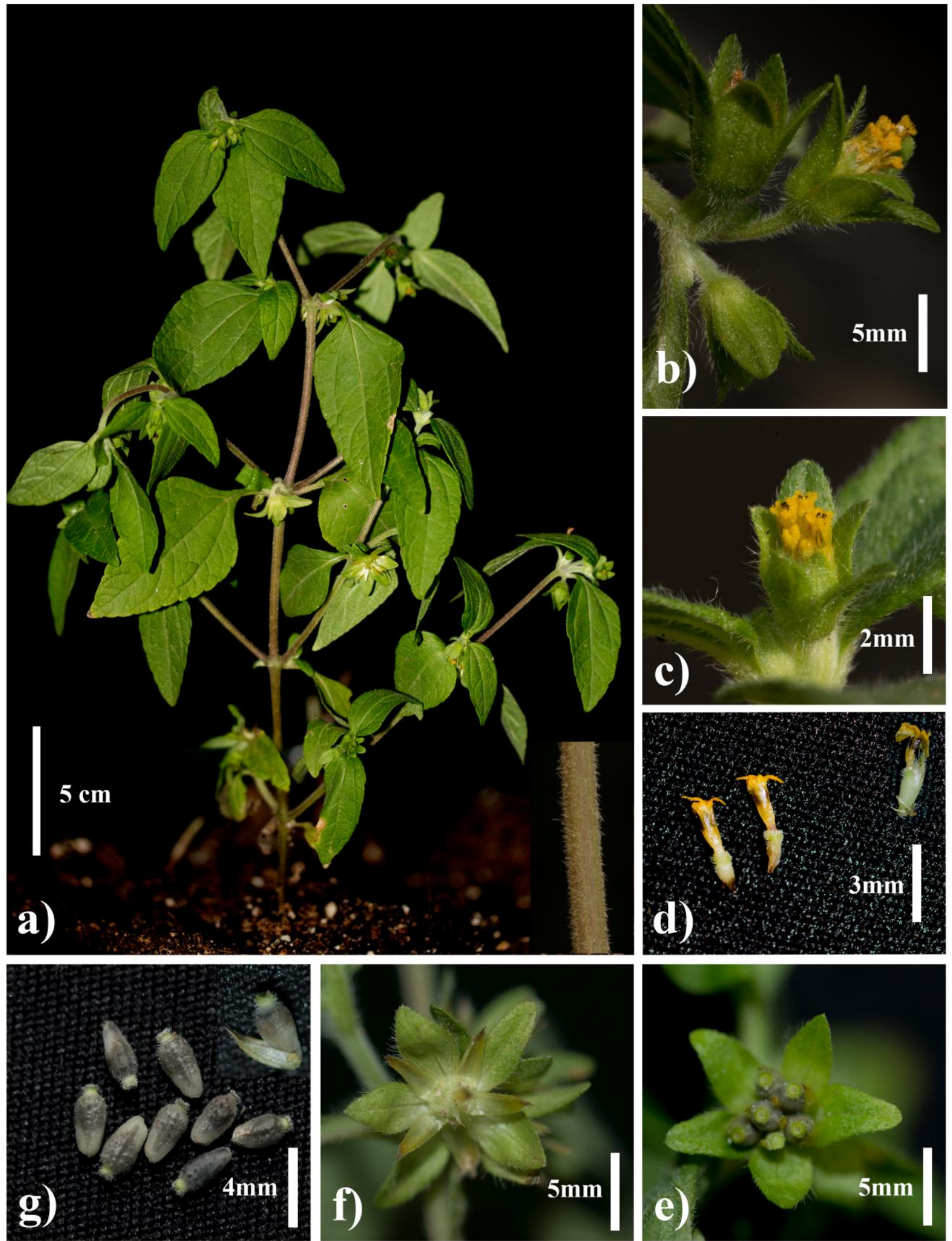

Fig.1: Eleutheranthera ruderalis (Sw.) Sch.-Bip. a) Habit, inset stem close up; b) Inflorescence; c) Capitulam close up; d) Disc florets; e) Involucre with immature achenes; f) Receptacular bract; g) Achenes close up. 


\section{Conflict of interest statement}

Authors declare that they have no conflict of interest.

\section{Acknowledgement}

Authors (RK, CPM \& KR) are thankful to the Management and Principal, Thiagarajar College, Madurai for their prolonged support. Second author (CR) is grateful to the Department of Science and Technology, SERB, N-PDF, Government of India, New Delhi, for financial assistance (File No: PDF/2015/000484; dt.10.03.2016).

\section{References}

Anderberg, A. A., Baldwin, B. G., Bayer, R. J., Breitwieser, I., Jeffrey, C., Dillon, M. O., Eldenas, P., Funk, V., Garcia-Jacas, N., Hind, D. J. N., Karis, P. O., Lack, H. W., Nesom, G., Nordenstam, B., Oberprieler, C., Panero, J. L., Puttock, C., Robinson, H., Stuessy, F., Susanna, A., Urtubey, E., Vogt, R., Ward, J., Watson, L. E., 2007. Compositae. In: Kadreit, J. W., Jeffrey, C., (Eds.) Flowering Plants. Eudicots, Asterales. Vol. VIII. Springer, Berlin, Germany.

Bennet, S. S. R., 1965. Eleutheranthera Poit.: A compositae genus new to Indian Flora. Curr. Sci. 34(13), 411.

Bhat, K. G., 1997. Additions to the flora of Karnataka . Indian J. Forest. 20, 103-104.

Choudhury, S., Mukherjee, S. K., 2005. Comparative morpho-anatomical study of some aspect in Eleutheranthera ruderalis (Sw.) Sch.Bip. and Synedrella nodiflora (L.) Gaertn. (Asteraceae). J. Econ. Taxon. Bot. 29(2), 364371.

Dassanayake, M. D., 1987. A Revised Handbook to the Flora of Ceylon. Vol. 1. Amerind Publishing Co. Pvt. Ltd. New Delhi, India.

Funk, V.A., Susanna, A., Stuessy, T. F., Bayer, R. J., 2009. Systematics, Evolution, and Biogeography of Compositae. International Association for Plant Taxonomy, Vienna, Austria.

Hajra, P. K., Rao, R. R., Singh, D. K., Uniyal, B.
P., 1995. Flora of India. 12. Asteraceae (Anthemidae - Heliantheae). Botanical Survey of India, Calcutta, India.

Henry, A. N., Kumari, G. R., Chithra, V., 1987. Flora of Tamil Nadu. India. Series-1: Analysis Vol. 2. Botanical Survey of India, Coimbatore.

Jana, B. K., Mukherjee, S. K., 2015. New report of Eleutheranthera rudralis (Sw.) Sch. Bip. from Nadia district of West Bengal with special reference to cypselar characters. In: Advancement in Plant Sciences (Eds.: Jana, B. K., Mukherjee, S. K.). ISBN: 978-3-659-669361. Advancement in Plant Sciences. Lap Lambert academic Publishing Saarbrücken, Germany. pp.54-57.

Jayaram, K. M., Pradeep, A. K., 1990. Notes on the Occurrence of Eleutheranthera ruderalis (SW) $\mathrm{SCH},-\mathrm{BIP}$, (Asteraceae) in Androth Island, Lakshadweep. Indian Forest. 116(7), 595-596.

Karthikeyan, S., Sanjappa, M., Moorthy, S., 2009 Flowering Plants of India. Dicotyledons, Vol. I. Acanthaceae - Aviciniaceae. Botanical Survey of India, Calcutta, India.

Kottaimuthu, R., 2014. Floristic studies on Dicots of Karandamalai, Southern Eastern Ghats, Tamil Nadu, India. Lambert Academic Publishing, Saarbrücken, Germany.

Krishnamurthy, K. V., Murugan, R., Ravikumar, B., 2014. Bioresources of the Eastern Ghats: Their Conservation and Management. Bishen Singh Mahendra Pal Singh, Dehra Dun.

Livingstone, C., Henry, A. N., 1994. The flowering plants of Madras city and its immediate neighbourhood. Madras Government Museum, Chennai.

Manickam, V. S., Jothi, G. J., Murugan, C., Sundaresan, V., 2003. Check-list of the flora of Tirunelveli Hills, southern Western Ghats, India. Tamil Nadu, India: Centre for Biodiversity and Biotechnology, St. Xavier's College.

Matthew, K. M., 1995. An Excursion Flora of Central Tamil Nadu, India. Oxford \& IBH Publishing Company, New Delhi.

Matthew, K. M., 1998. An enumeration of the Flowering plants of the Tiruchirapalli district with brief notes for each (1279) species. In: 
Gazetteers of Tamil Nadu: Tiruchirapalli district (Ed.: Velmani, K. S. K.). Volume 1. Chennai: Tamil Nadu Archives.

Matthew, K. M., 1999. The flora of the Palni Hills, South India. Part II. The Rapinat Herbarium, Tiruchirapalli.

Mitra, S., Mukherjee, S. K., 2017. Asteraceae of India: its Diversity and Phytogeographical Affinity. In: Plant Biodiversity: Monitoring, Assessment and Conservation (Eds.: Ansari, A. A., Gill, S. S., Abbas, Z. K., Naeem, M.). CABI, USA.

Nayar, T. S., Begam, A., Sibi, M., 2014. Flowering plants of the Western Ghats, India. Vol. 1. TBGRI, Thiruvananthapuram.

Nayar, T. S., Beegam, A. R., Mohanan, N., Rajkumar, G., Sibi, M., 2006. Flowering Plants of Kerala- A Handbook. TBGRI, Thiruvananthapuram, Kerala.

Pallithanam, J. M., 2001. A pocket Flora of Sirumalai Hills, South India. The Rapinat Herbarium, St. Joseph's College, Tiruchirapalli. Panero, J. L., 2007. Heliantheae. In: The Families and Genera of Vascular Plants (Eds.: Kadreit, J. W., Jeffrey, C.). Vol. VIII. Flowering Plants. Eudicots, Asterales. Springer, Berlin, Germany.

Rao, R. R., Choudhery, H. J., Hajra, P. K., Kumar, S., Pant, A. C., Naithani, B. D., Uniyal, B. P., Mathur, R., Mamgain, S. K., 1988. Florae Indicae Enumeratio: Asteraceae. Botanical Survey of India, Calcutta, India.

Sankar, R. V., Ravikumar, K., Ravichandran, P., 2012. Plant Resources of Tiruvannamalai District, Tamil Nadu, India. Mahendra Pal Singh, Dehra Dun.

Sasidharan, N., Nambiar, V. P. K., 1981. Eleutheranthera ruderalis (Sw.) Sch.-Bip. (Compositae) - A new record for South India. Indian J. Forest. 4, 240-241.

Vasudeva Rao, M. K., 1982. Six neophytes in Andaman and Nicobar Islands. Bull. Bot. Surv. India 22, 112-114.

Yang, S.-Z., Hsieh, G.-P., 2006. Eleutheranthera ruderalis (Swartz) Sch.-Bip. (Asteraceae), a newly naturalized plant in Taiwan. Taiwania 51(1), 46-49.

\section{How to cite this article:}

Kottaimuthu, R., Rajasekar, C., Muthupandi' C. P., Rajendran, K., 2018. Eleutheranthera Poit. ex Bosc. (Asteraceae): A new genus record for Tamil Nadu, India. Int. J. Curr. Res. Biosci. Plant Biol. 5(12), 62-66. doi: https://doi.org/10.20546/ijcrbp.2018.512.008 